\title{
DARNUS EKONOMIKOS VYSTYMASIS: ETINIAI IR DVASINGUMO PAGRINDAI
}

\author{
Remigijus Čiegis ${ }^{1}$, Algirdas Gavenauskas ${ }^{2}$, Anželika Dautartė², \\ Juozas Pekarskas ${ }^{2}$, Rūtenis Jančius ${ }^{3}$ \\ ${ }^{I}$ Vilniaus universitetas, ${ }^{2}$ Aleksandro Stulginskio universitetas, \\ ${ }^{3}$ Kauno statybos ir paslaugu mokymo centras
}

\begin{abstract}
Anotacija
Darnaus vystymosi filosofija lemia prasmingesni žmogaus ir visuomenės vystymąsi. Darnaus vystymosi samprata ir suvokimas yra svarbūs praktiniam taikymui žmogaus gyvenime. Straipsnyje aptariamos šiuolaikinès ekologinès kultūros mokslinès problematikos priežastys, šiuo metu stebimas socialinių ir gamtinių prieštaravimų paaštrèjimas, darnaus vystymosi etiniai aspektai, akcentuojant ekologinès sąmonès, ekologinès kultūros ir dvasingumo svarbą, darnaus vystymosi pletros perspektyvos. Straipsnyje akcentuojamas dvasingumas, nes kiekvienoje kultūroje egzistuojančios savitos vertybès ir vertybinès orientacijos veikia ne tik kultūros narių pasaulěžiūrą, bet ir gyvenimo suvokimą.

PAGRINDINIAI ŽODŽIAI: darnus vystymasis, ekologinė sąmonė, ekologinė kultūra, etika, dvasingumas, vertybinès orientacijos, žmogaus dvasingumo svarba darnaus vystymosi sampratoje.
\end{abstract}

\begin{abstract}
Sustainable development philosophy leads to meaningful human and social development. Sustainable development concept and perception is very important, it should influence the practical application of human life. The article deals with modern problems of ecological culture scientific reasons, currently monitored social-natural contradictions aggravation, sustainable development with emphasis on the ethical aspects of ecological consciousness, ecological, cultural and spiritual importance of sustainable development for future development prospects. The article emphasizes on spirituality, because in each culture existing distinctive values and values orientation affect not only the worldview of society but also the perception of life.

KEY WORDS: sustainable development, ecological consciousness, ecological culture, ethics, spirituality, values orientation, the importance of human spirituality in the concept of sustainable development.
\end{abstract}

DOI: http://dx.doi.org/10.15181/tbb.v76i1.1514

\section{Ivadas}

Žmonija įžengè ị XXI amžių, naują tūkstantmetị, kai turètų susiformuoti iš esmès naujas požiūris ị mus supančią aplinką, mokslo ir technikos pažangą, ịvairių kultūrų bei tradicijų integraciją ir tolesnę ekonomikos raidą. Praejjusị šimtmetị išbandytos ekonominès plètros koncepcijos šiandien jau nebegali tenkinti žmonijos. Reikia naujos globalios ekonominès teorijos, kuri turètų pakoreguoti dabar vyraujančios ekonominès filosofijos, ,ignoruojančios fizinị pasaulį“ ir įteisinančios 
ar net skatinančios ekologinę destrukciją, trūkumus (Čiegis, 2002, p. 6-7). Antropogeninis poveikis gamtinei sistemai globalizacijos sąlygomis atvedė žmoniją prie ekologinès krizès, „,kuri yra nekontroliuojamos žmogaus veiklos dramatiškas padarinys“ (Pranciškus, 2015, p. 4). „Dramatiškos krizės“ išvengti galima tik pakeitus socialinio ir kultūrinio vystymosi orientyrus. „Žmogus savo veikimu turèjo prisijungti prie gamtinès kūrybos, ją patobulinti, pakelti ị aukštesnị būties laipsnị ir atbaigti“ (Maceina, 1992, p. 144). Žmogus savo darbu ne tik prisideda prie gamtos pertvarkos, bet ją pritaiko savo poreikiams, kartu realizuojasi kaip žmogus.

Nauja technologijų epocha ir galia verčia žmoniją rinktis, kokiu keliu toliau žengti. Moksline ir technologine pažanga galima pagrịstai džiaugtis dẻl suteiktų didžiulių galimybių, kadangi mokslas ir technologijos yra žmogui dovanoto kūrybiškumo, kartu ir misijos pripildyti žemę ir užvaldyti laikantis įstatymo, vaisius (Pranciškus, 2015; Jonas Paulius II, 2004). Nepaisant teigiamų technologijų aspektų, kurie prisidèjo prie darnụji vystymąsi lemiančių alternatyvų, negalima nematyti to, kad per pastaruosius šimtą penkiasdešimt metų visas mūsų planetos gyvas būtybes įstūmè iš esmès ị naują situaciją. Didesnę materialinę gausą, aukštesnị gyvenimo lygị, geresnę sveikatą ir ilgesnę gyvenimo trukmę lydejo oro ir vandens tarša, nuodingų pramoninių atliekų, trapių habitat išnaudojimo, kartais ir sunaikinimo problemos (Tarptautinè teologijos komisija, 2005; Pranciškus, 2015). Gamta - biosfera, kurioje gyvieji organizmai sudaro sudètingą, organizuotą gyvybès tinklą, o gamtos ištekliai geba atsigauti nuo padarytos žalos. Dramatiška ekologinè krizè skatina žmonijos atsivertimą - ekologinį, to pasekmès reiškiasi santykyje su aplinkiniu pasauliu, nes ,žmogaus valdžia yra ne absoliuti, bet tarnaujamoji, <..> ne absoliutaus ir neginčijamo šeimininko, bet Dievo karalystès tarnautojo misija“ (Pranciškus, 2015, Nr. 5).

Žmogus kaip dovaną gauna žemę su visu tuo, kas joje yra, visiems žmonėms ir tautoms, kad naudotųsi sukurtosiomis gèrybėmis vadovaudamasis teisingumu, meile ir pasiektų visus žmones (Paulius VI, 1967). Nerimą kelia besaikis vartotojiškumas ir su juo glaudžiai susijusi ekologija. Trokštama vis daug turèti ir mègautis, negu būti ir tobulèti, žmonija nesaikingai vartoja žemès išteklius ir savo pačių gyvenimą, kaip vertybę, kuri yra dovana.

Žmogus pašaukiamas įdirbti pasaulio sodą ir juo rūpintis (plg. Pr 2, 15). Sukurtas pasaulis patikètas žmogui, jam suteikta galia, kartu ịpareigojimas valdyti visą kūriniją. Pašaukimas tampa žmogaus išaukštinimu, bet tai neturi tapti savavališku ardomuoju valdymu. Žmogus atsakingas ne tik už savo gyvenamają aplinką, bet ir už būsimų kartų gyvenimo kokybę bei kiekybę (Jonas Paulius II, 1995; Pranciškus, 2015). Popiežius Jonas Paulius II jau pirmojoje savo enciklikoje, kuri paskelbta 1979 m., pažymėjo, kad aplinką būtina išmintingai tvarkyti. 
Didelis dèmesys turètų būti skiriamas ekologiškai darnaus vystymosi idejjai. İžengus į naujajị tūkstantmetị, vienas svarbiausių, gal net pats svarbiausias klausimas yra tai, kaip įvertinti ir išlaikyti darnią ekonomiką, kuri leistų žmonių visuomenei naudotis gana aukštu gyvenimo standartu nesuardant jos gamtinių ir biologinių pamatų (Čiegis, 2002, p. 8). Bet ar bus įmanoma ateityje igyvendinti darnų vystymąsi, neatsižvelgiant ị kultūrinius procesus, psichologinius ịvairių sociumų ypatumus? Struktūriniai pokyčiai turi užtikrinti darnų žmogaus ir gamtos vystymąsi, iggyvendinti ši siekị bus galima tik tada, kai problema bus artima ir suprantama kiekvienam žmogui, tai yra, jei įvyks vidinio žmogaus pasaulio transformacija, susijusi su kardinaliais jo kultūros, vertybių, minčių, gyvenimo būdo ir pasaulèžiūros pasikeitimais.

Visuomenès sąmoningumo ekologizacija dèl savo socialinio reikšmingumo turètų užimti ypatingą vietą mokslinio pažinimo vystymesi. Jungtinių Tautu aplinkosaugos programa ekologinị švietimą pripažino kaip vieną darnios pagrindinių žmogaus ir gamtos sąveikos priemonių. Ekologinis švietimas padètų susivokti susidariusios ekologinès situacijos, pasiekusios kritinị lygị, mastus ir pavojus.

Gamyba visose pramoninèse šalyse vis labiau iggauna gamtą ardantį ir alinantị pobūdị, galiausiai nukreiptą prieš patị žmogų. Šiuolaikinėmis sąlygomis ekologinè sąmonė formuojasi suvokus gamtos pokyčius, kuriuos lèmé gamybinė veikla (gamybos procesai dramatiškai kilstelëjo ne tik gamybos, bet ir taršos lygi), ir pripažistama būtinybè spręsti ekologines problemas. Tiek ekologinè, tiek dvasinè krizė, gresianti žmonių sveikatai ir saugumui, esamoje švietimo sistemoje vis dar iki galo neịsisąmoninta.

Manome, kad nekorektiška būtų žmogų kaltinti tuo, kad jo sąveika su gamta yra pragmatinio pobūdžio ir kad taip jis gamtą griauna. Žmonès, didindami sociogamtinès sistemos ịvairovę, riboja gamtinių sudètinių dalių ịvairovę, apsupo save dirbtinai veisiamais gyvūnais ir augalais, išravejjo piktžoles, nustūmè pavojingus plèšrūnus, nuodingąsias gyvates bei vabzdžius. Taip biocenozės antropocentravosi ir antropomorfizavosi, jų elementų sudètis, elgesys ir gyvūnų refleksai prisitaikè prie gausėjančių žmogaus buvimo ženklų (Бахарев, 1999).

Žmogus savo darbo ir talento dèka visada stengèsi plèsti savo gyvenimo ribas. Pasitelkęs mokslą ir techniką, jis užvaldè kone visą gamtą ir vis labiau ją užvaldo, ypač dèl to, kad padaugèjo ịvairių mainų tarp tautų galimybių. Žmonijos šeima pamažu tampa tarsi viena visą pasauli apimanti bendruomenè. Todèl „daugelị gèrybių, kurių kitados dažniausia laukè iš aukštybių, šiandien žmogus pasirūpina savo paties sumanumu“ (Vatikano II Susirinkimo nutarimai, Gaudium et spes, 2001, Nr. 33).

Straipsnio tikslas: išskirti pagrindines žmogaus ir gamtos santykių apraiškas, pateikti ekologinès etikos ideologinị ryšị su Kūrèju ir Žmogumi, ir jos pri- 
taikymo galimybes ugdant darnų, atsakingą žmogaus santykị su gamta, siekiant išsaugoti sveikesnę, mažiau antropogeninès veiklos pažeistą aplinką būsimoms kartoms, išryškinti tam tikras etinio pobūdžio nuostatas, teikiančias moralès subjektams optimistinę viltị suderinti civilizacijos pasiekimus su amžinomis humanistinèmis vertybėmis.

Straipsnio objektas: darni plètra krikščioniškame mokyme.

Metodai: straipsnis parengtas taikant sisteminès mokslinès literatūros analizès, bendrosios ir loginès analizès, lyginimo ir apibendrinimo metodus.

\section{Darnaus vystymosi filosofijos svarba žmogaus ir visuomenės gyvenime}

Visuomenès plètra ilgą laiką buvo neatskiriamai susijusi su vis didejjančiu poveikiu aplinkai. Eksponentiškas pastarujų šimtmečių ekonomikos ir žmonių skaičiaus augimas lèmé intensyvesni gamtos išteklių naudojimą ir aplinkos teršimą. Nuo praejjusio šimtmečio vidurio dèl mokslinès-techninès revoliucijos gamybos ir gamtos išteklių naudojimo augimo tempai šoktelèjo dvigubai, o žmonių skaičiaus augimas iggavo demografinio sprogimo pobūdị. Tai lèmè ir daug spartesnę aplinkos taršą, kuri septintajame XX amžiaus dešimtmetyje pasiekè tokị lygị, kad šiai problemai ir toliau neskirti dẻmesio buvo nebeịmanoma (Gustainis ir kt., 2002). Žmogus vietoj gamtos sargo tapo jos eksploatatoriumi, o darbų pasekmè pasieké nematytą mastą. Žmogaus kūryba ėmė grèsti pačiam žmogui, nes trūksta dvasinio sąmoningumo. Kaip pastebejjo Č. Kalenda (1998), gamtos negalima ignoruoti, jos negalima nugalèti, su ja galima tik koegzistuoti. Žmonija ima suvokti, kad besaikis planetos eksploatavimas verčia racionaliai ir sąžiningai planuoti. „Toji eksploatacija - ne tik pramoniniais, bet ir militaristiniais tikslais - technikos vystymasis, nekontroliuojamas visaapimantis planavimas dažnai atneša natūralios žmogaus aplinkos užteršimą, atitraukia žmogų nuo gamtos. Dažnai žmogus atrodo nepastebįs savo natūralios aplinkos kitos reikšmès, kaip tą, kuri tarnauja naudojimo ir suvartojimo tikslams““ (Jonas Paulius II, 1979). M. K. Hubbertas turbūt buvo teisus sakydamas, kad eksponentinis augimas yra tik laikinas fenomenas žmonijos istorijoje (Hubbert, 1992).

Pirmasis Europos ekumeninis susirinkimas, vykęs Bazelyje 1989 m., parengè 1990 m. kovo 5-12 d. Seule vykusị Ekumeninès bažnyčiu tarybos susirinkimą, kuriame nagrinèta ta pati tema „Teisingumas, taika ir kūrinijos išsaugojimas“. Susirinkime patikslinta žodžių valdyti žeme prasmė ir smerkiamas šiais žodžiais dangstomas piktnaudžiavimas: „Žmonija nemokèjo mylèti žemès ir joje esančios gyvybès, bet beatodairiškai plèše jos turtus ir galias, tarsi ji būtų buvusi sukurta egoistiniams tikslams tenkinti. Padaryta žala tokia didelè, kad gali būti nebeatitaisoma“" (Ekologija teologijos požiūriu, 1997). Susirinkimo nariai pastebejjo, kad 
posakiai valdyti žemę ir pavergti amžiais tarnavo darnios tvarkos griovimo veiksmams pateisinti. Tą pati daro ir šiandieninè žmonija (Pivrikas, 2008).

Be abejo, pagrindinis švietimo, būtino darniam vystymuisi, tikslas - žmoniu sąmonès ir veiksmų pokyčiai. Mus supančios aplinkos ekologinių problemų sprendimas, kaip ir jų kilimas, lemtingai priklauso nuo intelektiniu ir kultūriniu aspektais ribotų žmonių. Būtent tokie, su retomis išimtimis, yra sprendimus priimantys žmonès, tokia yra žmonių, kurių elgesys ir veikla šias problemas sukuria, masė (Брудный, 1998). Ekologinė krizė pirmiausia yra etinè, psichologinè, kultūrinè ir religinè, o ne technologinè problema. Pagrindinis darbas turètų būti atliktas ne technika, ne taikant mokslo ir technikos pažangos laimejjimus, o pasitelkus žmogaus sąmonę (Данилов, Данильян, 2001). Žemas šalies gyventojų, profesionalų ir valdžios atstovų, priimančių sprendimus šiose srityse, ekologinès sąmonès ir kultūros lygis yra lemiamas ekologinès degradacijos veiksnys, be abejo, tapsiantis barjeru, pereinant prie darnaus vystymosi. Vienintelè reali išeitis iš šios aklavietės - tolydumo etikos tolesnè plètra, atkuriant vientisą pasaulio vaizdą ir žmogaus ryši su gamta. Akivaizdu, kad mums reikia tiksliau įvertinti žmogaus poveiki biosferai, patobulinti ūkio ir aplinkos valdymo galimybes, ịgyti šiuo požiūriu tinkamesnị išsilavinimą ir didinti savo sąmoningumą. Kelias ị naują gyvenseną ir kitokią vartoseną turètų būti grindžiamas nauju požiūriu ị žmogų ir jị supančią aplinką. Elgsenos su gamta pagrindimo prasme išskirtinas minètas šv. Pranciškus Asyžietis - didžiausias Vakarų istorijos dvasios revoliucionierius, ,,antrasis Kristus“, pirmaisiais savo pontifikavimo metais popiežiaus Jono Pauliaus II paskelbtas šventuoju globeju tų, kurie užsiima gamtosauga, îvardytas kaip ,tikros ir gilios pagarbos visatos vientisumui pavyzdžiu krikščionims“" (Jonas Paulius II, 1979).

Priimant ūkinius sprendimus, plètros planus, naujų technologijų kūrimo ir diegimo programas, nebepakanka vien ekonominès informacijos ir siaurai suprastu ekonominio efektyvumo kriterijų. Būtini kiti kriterijai - ekologiniai ir doroviniai, kurie lemia pasaulio raidos perspektyvą, žmoniu giminès sveikatą ir išlikimą. Būtent ekologinis ir dorovinis imperatyvas nubrèžia tą lemtingą ribą, kurios nevalia peržengti (Čiegis, 2002, p. 10). Taigi ir darnus vystymasis turètų būti vertinamas ne tik ekonomiškai, bet ir žmogaus, kaip visumos, jo pašaukimo pasaulyje vidinių dvasinių parametrų kontekste. Visose Rytų ir Vakarų filosofijose, religijose nuo pat žmonijos istorijos pradžios atrandame keturias dimensijas: fizinę (ekonominę), protinę, socialinę (emocinę) ir dvasinę. Jos atskleidžia keturis pagrindinius visos žmonijos poreikius ir motyvacijas: gyventi (išlikti), mylèti (bendrauti tarpusavyje), mokytis (vidine branda ir vystymasis) ir būti naudingam (gyventi prasmingai ir palikti pèdsaką) (Covey, 2007).

Nepaneigiama, kad žmogui sukurtos gèrybės yra būtinos, pramonė kuria gaminius, taikydama mokslinès-technologinės pažangos metodus. Tačiau kyla piktnau- 
džiavimo vartojimu pavojus, nors dirbtinių poreikių atsiradimas negali kliudyti pagarbai ir naujų gèrybių bei naujų išteklių, esančių žmonijos žinioje, naudojimui (Jonas Paulius II, 1987). Svarbu suvokti, kad gamtos ištekliai žmonijai yra dovana, kartu ir atsakymas, jog žmogus pašauktas darniam vystymuisi, juos panaudojant žmonijos gèriui. Pažanga ir vystymasis negali būti besaikis sukurtų daiktų ir žmogiškos pramonès gaminių naudojimas, valdymas ir turejjimas. Žmogus turèjimą, valdymą ir naudojimą turi gebėti ịprasminti savo pašaukime (Jonas Paulius II, 1987).

Darnus vystymasis apima žmonių gebèjimą vengti taršos ir rūpinimąsi ištekliais, kurie moko žmogų gyventi dèkojant ir atleidžiant, o ne puoselejjant vartotojiškumą bei gobšumą (Barbour, 2000). Pažangos autorius ir kūrèjas žmogus savo gyvenimą žemėje padaro visapusiškai „labiau žmonišką“, bet ar tai lemia labiau „vertą žmogaus“? Daugeliu atvejų - taip, bet ar žmogus, kaip toks, šios pažangos kontekste tampa geresnis, dvasiškai ir vidumi brandesnis, labiau ịsisąmoninęs savo žmogiškajji orumą, atsakingesnis, labiau prieinamas kitiems (Jonas Paulius II, 1979).

Labai svarbu išsiaiškinti ir suvokti, ar žmonès XXI a. pradžioje suprato, kad dèl jų veiklos gamtai ir jiems iškilo grèsmè, ar suvokè, kad negalima toliau gyventi puoselèjant dvasinị egoizmą, vis laikant save „gamtos viešpačiu ir kūrejju“? (Baranova, 2000). Ieškant atsakymų ị šiuos klausimus žmonijai iškilo būtinybe kiek įmanoma restauruoti antikinėmis panteistinèmis tradicijomis grịstą požiūrị ị pasaulį, pasisakiusį už pasaulio ir žmogaus darną, gamtos gerbimą: suvokę, kad žmogus ir gamta yra vienos prigimties, su aplinkiniu pasauliu elgtumèmès paprasčiau, jo negriautume.

Žmogaus ir gamtos konflikto pasekmè yra pasaulio ekologinè, moralinè, socialinè krizè, tapusi viena aktualiausių ir neatidèliotinai spręstinų problemų pasaulyje. Dabartinis žmogus turtingiausias savinaikos priemonių, tačiau gerokai nuskurdęs doroviniu, vertybiniu požiūriu, o tai gali padèti išsigelbèti ir išgelbèti gamtą. Žmogus privalo ịveikti vidinị chaosą, suvaldyti pirminius instinktus, susitvarkyti vidini gyvenimą.

Darnaus vystymosi filosofija pabrèžia bendrujų žmogiškujjų vertybių prioritetą, teigia, kad gamtos išsaugojimas yra bendras ir svarbiausias visos žmonijos uždavinys. Ji kviečia liautis išnaudoti gamtą ir pradèti bendradarbiauti su mus supančiu grožiu bei gèriu, esančiu kiekvieno mūsų viduje. Žmonija privalo priimti tiesą, kad pasaulis jai dovanotas. Pasauliui būdinga dovanos struktūra ir jame regimi meilès pėdsakai. Žmonija, išmokusi gerbti, galès perimti karaliaus tarno nuostatą. Karalius nèra tas, kuris naikina, bet tas, kuris rūpinasi viskuo, kas jam patikèta. Žmonijos moralinis vystymasis neatsiejamas nuo pagarbos visoms būtybėms, su- 
darančioms matomą gamtą, kurią graikai, primindami jos ypatingą tvarką, pavadino kosmosu (Jonas Paulius II, 1987).

Tikrovè, kurioje gyvena žmonija, skatina ne tik pagarbą, bet ir verčia ịsisąmoninti, kad negalima nebaudžiamai naudotis ịvairiomis būtybėmis, gyvomis ir negyvomis, be saiko tenkinant savo asmeninius ekonominius poreikius. „Priešingai, reikia atsižvelgti ị kiekvienos būtybẻs prigimtị ir jų tarpusavio ryšius darnioje visatos sistemoje. Žmonija privalo nepamiršti, kad gamtos ištekliai nèra neišsenkami ir daugelis iš jų yra neatsikuriantys. Besaikis, beatodairiškas jų vartojimas kelia rimtą pavojų ne tik dabartinei, bet ypač ateinančioms būsimosioms kartoms. Teisinga vystymosi koncepcija negali atitrūkti nuo šių vertinimų, susijusių su gamtos elementų naudojimu, išteklių atnaujinimu ir nežabotos industrializacijos padariniais, nes nuo to priklauso mūsų sąmonè, moralè, kuri yra esminè vystymesi“ (Jonas Paulius II, 1987, Nr. 34).

Šios darnaus vystymosi filosofijos sampratos rèmèjai turètų siekti derinti žmogaus ir gamtos santykius. Darnus vystymasis buvo įteisintas kaip pagrindinè visuomenès raidos ideologija. Tai žmonijos raidos ateitimi susirūpinusios, gamtai neabejingos sąmonès reakcija ị civilizacijų kaitoje susiklosčiusią gyvybei nepalankią ekologinę situaciją. Darnaus vystymosi filosofija kviečia „vidiniam atsinaujinimui“, skatina norą viešpatauti keisti susitarimu su Gamta, pagrindžia kiekvieno Planetos gyventojo moralinę atsakomybę už savo elgesio padarinius Gamtai ir Žmogui. Privalome diegti suvokimą, kad holistinis požiūris, apimantis antropologiją, etiką, filosofiją ir akcentuojantis Žmogų, Moralę ir Išmintį, yra svarbiausia žmonijos ir gamtos apsaugos sistema.

Net ir ištikus pasaulinei ekologinei, moralinei, socialinei krizei žmogus negali žūti. I̦veikęs tiek krizių, žmogus įveiks ir šią. Jis yra savyje „suskilęs“, todèl visas jo gyvenimas - ir asmeninis, ir bendruomeninis - pasireiškia kaip kova, dažnai dramatiška, tarp gèrio ir blogio, šviesos ir tamsybių (Vatikano II Susirinkimo nutarimai, Gaudium et spes, 2001). Žmogus, nors ir ignoruoja ekologines problemas, vis dèlto išlieka nelygstama vertybè. Jis dirba, atlieka ịvairius darbo procesui priklausančius veiksmus, visa tai turi jam padèti ịgyvendinti jo žmogiškumą, vykdant asmenini pašaukimą, kuris jam būdingas dèl jo žmogiškumo (Jonas Paulius II, 1981). Protinè žmogaus prigimtis yra ir turi būti tobulinama, remiantis išmintimi, kuri švelniai kreipia jo dvasią ieškoti ir mylèti tai, kas teisinga ir gera. „Pasisavinus išmintị, regimi dalykai žmogų veda ị neregimuosius“ (Vatikano II Susirinkimo nutarimai, Gaudium et spes, 2001, Nr. 15). Žmogus, ignoruodamas Kūrèjo išmintį, save stato aukščiau Kūrèjo, pamiršdamas savo, kaip kūrinio, ribotumą Kūrejo ir pasaulio atžvilgiu. 


\section{Dvasingumas ir ekologija šiuolaikiniame pasaulyje}

Visuomenès vystymosi paradigma - vienas šiuolaikinio pasaulio, įtraukto ị globalinị permainų procesą, skiriamujų ženklų. Socialinès-ekonominès permainos žmogui dažnai tampa ribinėmis situacijomis, kurios patikrina jo egzistencijos patvarumą. Ekologini asmenybės potencialą apibrèžia žmogiškosios prigimties galimybės, stabilaus egzistavimo pasaulyje psichinis išteklius. Ekologinis sąmonès potencialas - kognityvios ir emocionalios asmenybès sistemos, sudarančios galimybę stabiliai egzistuoti. Tai emociškai nuspalvintas požiūris ị gyvenimą, gamtą, žmogų. Ekologinès sąmonès potencialo kryptis - tiek ị asmeninès ir visuomeninès grèsmès šalinimą, tiek ị pozityvią savimonę, kuri užtikrintų gamtos ir paties subjekto būklès vientisumą. Ekologinè šiuolaikinio žmogaus sąmonè neprisitaikiusi spręsti ekologinių problemų. Norint pagerinti žmogaus aplinkos būklę, sumažinti ekologinę grèsmę, būtina keisti žmonijos vystymosi kryptį, stiprų poveikị civilizacijai keičiant silpnesniu (Петрова, 2005).

Vartojimo apimčių mažinimo suvokimas, gyventojų prieauglio stabdymas, socialiai reguliuojant biologini gyvenimą ir žmogaus siekius, neatsako už darnų vystymąsi, kaip už augantị procesą. Gamtos išteklių ribotumo suvokimas lemia visuotinių poreikių minimalizavimą. Poreikių atsisakymas šiuolaikiniam žmogui yra vienas iš depresijos, vystymosi apribojimo simptomų. Tai formuoja ribotą žmogų. Vargu ar tai pageidaujamas vystymosi variantas. Darnus vystymasis apima gamybinių jègų derinimo procesus, visuomenès narių būtinų poreikių patenkinimo užtikrinimą, išsaugojant ir atkuriant gamtos aplinkos vientisumą, sudarant galimybę išlaikyti pusiausvyrą tarp gamtos ir visų kartų žmonių poreikių. Taigi ekologiškai mąstantis ir taip besielgiantis žmogus turi būti orientuotas ne į kovą su gamta, o ¡̇ darną, santarvę su ja. Norvegijos ministrès pirmininkès Gro Harlem Brundtland „Sero Peter Scott paskaitoje“, kuri skaityta 1986 m. spalio 8 d. Bristole, žodžiais tariant, ,jeigu mes rūpinsimès gamta, gamta rūpinsis mumis“(Čiegis, 2002, p. 40).

Žmogus gyvena sparčiai besikeičiančiame pasaulyje, visur ir visada skuba nenori, negali ir bijo sustoti, tarsi trumpas stabtelejjimas, ilgesnis įsiklausymas $i$ save ar gamtą gali ji nenumaldomai sustabdyti ir priversti palikti pirmaujančiu „skubėtojų“ gretas. Ekologinis sąmonès potencialas leis išraizgyti šiuolaikinių prieštaravimų kamuolị, išvengti pavojų, žalos, grèsmių, traumų, praradimų ar netekčių, atsisakyti instinktyvaus požiūrio ị realybę chaoso, plečiant sąmoningo požiūrio sritị, priimant savo pačių prigimties realybę ir suprojektuojant ṣ̌ suvokimą i žmogaus aplinką. Ekologinès sąmonès potencialas slypi esminiame psichologinių problemų suvokime, ieškant jų sprendimo. Tai praejusioms epochoms būdingo žmogaus išaukštinimo, jo „tamsiujų pusių“ ignoravimo, slopinimo, nutylèjimo galimybės, kad gali egzistuoti tobulas, darnus, neprieštaringas žmogus, propagavimo 
rezultatas. Nesugebejjimo susidoroti su savo pačiu psichologinėmis problemomis pasekmè - šių problemų perkèlimas ị santykius su gamta (Петрова, 2005).

Manome, kad išeitis - vidinè žmogaus transformacija, siekiant mažinti dvasinę-moralinę visuomenès ir žmogaus tapatybès krizę, stabdyti vidinio tapatumo irimo procesus, plečiant dvasinès savivokos erdvę, nekuriant saugos, „tariamos“ tvarkos dvasios apmirimo, neslopinant širdies vidinio gyvojo gyvenimo ištuštèjimo kaina, rūpinantis ne tik savimi, bet ir kito žmogaus buvimu šalia, kuriant ir palaikant kultūrinị klimatą, be kurio nę̧manomi kiti, reikšmingesni žingsniai, stiprinant žmogiškajį orumą - tokia yra darnios plètros samprata.

\section{Ekologinès etikos ir kultūros svarba, siekiant vystymosi darnos}

Darnūs ekonominiai sprendimai negali nebūti ekologiški, taigi jie galimi tik fundamentaliai pasikeitus žmonių vertybinèms nuostatoms ir atsiradus naujai etikai, naujam požiūriui ị gamtą, numatant visų mūsų atsakomybę puoselèti sveikus santykius su gamta. Prieš priimdami darnų vystymąsi kaip naują etiką ir naują ekonomikos strategiją, turime žinoti, kokiomis ekologinèmis, socialinėmis, politinėmis ir asmeninėmis vertybėmis ji grindžiama ir kaip ji sutaiko mūsų moralines idẻjas apie žmonių laisvę, lygybę ir gerovę su mūsų ịsipareigojimais gyvūnams, rūšims ir ekosistemoms (jei naujoji etika iš tiesų yra apie tai). Pirmasis ir svarbiausias yra darbas, vykstantis žmogaus širdyje, o kaip jis angažuojasi kurti savo ateiti, priklauso nuo to, kaip supranta save ir savo paskirti (Jonas Paulius II, 1991).

Ekologinè etika, „Romos klubo“ ịkūrejjo Aurelio Peccei pavadinta aukščiausia etikos forma, kuri užtikrina žmonių giminès išlikimo galimybę, kaip etikos tyrimų sritis, yra XX amžiaus, ypač paskutiniujjų trijų dešimtmečių, kūdikis. Ekologinè etika atgaivino svarbiausias mąstytojų B. Spinoza, F. Schelling, S. Coleridge, J. V. Goethe, R. Emerson, A. von Humboldt, H. D. Thoreau, M. Gandhi, R. Tagore, F. Dostojevskio, L. Tolstojaus, V. Solovjovo, A. Schweitzer, N. Rerich, A. de SaintExupery, J. Muir, A. Leopold universalios etikos idejas (Кошелева, 1993). Ekologinė etika, kuri ypač pabréžia bendražmogiškųjų vertybių prioritetą, nes gamtos išsaugojimas - bendras ir svarbiausias žmonijos uždavinys, kaip nauja moderni etikos mokslo šaka, viena pagrindinių savo užduočių siekia suderinti aplinkonaudos santykius. Be to, ji aktualizuoja ne tik bendražmogiškuosius, bet ir pasaulinès dorovès principus, gina visos esamybès teisę ị būtį, akcentuoja pagarbą gyvybei, darnią visuomenès ir gamtos raidą.

Ekologinès kultūros sąvoka yra gana nauja, ji dar tik formuojasi, dèl jos vyksta moksliniai ginčai, išsakomos priešingos nuomonès. Tai sudètingas struktūrinis darinys, kuriame išsiskiria tokie struktūriniai elementai, kaip ekologiniai pagrindai ir ịsitikinimai, socialinès vertybinès asmenybès elgesio bei veiklos sociogamtinėje 
aplinkoje nuostatos, estetiniai prigimtinės terpès vertinimai, ekologiškai pagrịstas savo gyvybinès veiklos vertinimas. Dauguma tyrèjų linkę laikytis nuomonès, kad vienu pagrindinių ekologinès kultūros struktūrą kuriančių elementų yra ekologinè sąmonè, nagrinejjama kaip viena iš visuomenès sąmonès formų. Ekologinè sąmonè yra subjektyvaus asmenybės požiūrio ị gamtą, ịsisąmonintų strategijų ir technologijų sąveikos su gamta visuma (Кужанова, 2005). Plèsti moralès turinį ir spartinti dorovinę pažangą, papildyti ją naujais principais ir maksimomis, skatinančiomis puoselèti gamtą, - tokia ekologinès etikos, kuri gilinasi ị žmogaus ir gamtinès sąveikos dorovinius aspektus, paskirtis: bioịvairovès ir gamtos pusiausvyros išsaugojimas, gyvūnų teisès ir jų apsauga, gamtos dorovinis statusas, kraštovaizdžio puoselëjimas. Ekologinès etikos tikslas - teisingas, sveikas ir prasmingas žmogaus gyvenimas žemèje bei gyvybès puoselëjimas. Meilè ir pagarba natūraliam žemės grožiui, būtinybė išsaugoti gamtos ịvairovę leidžia apibūdinti darnų vystymąsi kaip etinį idealą (Kothari, 1994). Būtina pastebèti, kad darnaus vystymosi etinei dimensijai mokslinèje literatūroje jau nuo XX a. paskutiniojo dešimtmečio skiriamas vis didesnis dèmesys (Daly, Cobb, 1989; Engel, Engel, 1990; Rockefeller, Elder, 1992; Brown, 1994; Engel, Denny-Hugher, 1994; Skolimowski, 1990).

Sèkmingai spręsti ekologines problemas galèsime, matyt, tik tada, kai visi ekonominiai, politiniai ir socialiniai mechanizmai bus sureguliuoti taip, kad skatintu pažangias, ekologiškai saugias technologijas ir aplinkai draugišką visų mūsų elgesị. Būtinas ne tik ekonomiškai ir ekologiškai, bet ir moraliai darnus vystymasis. Darni ekonomika gali būti mūsų ilgalaikès plètros tikslas, bet tam būtina užtikrinti pagrindinius dabar gyvenančių žmonių gyvybinius poreikius ir būsimų kartų išlikimą - tai prioritetas, palyginti su dabartinių kartu gyvenimo poreikių tenkinimu. Galime teigti, kad tolydumas yra labiau normatyvinis etinis principas, siekiant tolesnio visuomenès vystymosi, daugiau bylojantis ne tai, kaip yra, bet tai, kaip turètų büti, ir numatantis nuolatinès žmonių santykių bei veiklos algoritmų kritikos reikmę (Čiegis, 2002).

Remiantis sinerginiu apibrèžimu, visuomenè yra netolygi ypatingo tipo sistema, kurios patvarumas užtikrinamas dirbtiniu išorinių su gamtine aplinka ir vidinių santykių puoselèjimu, o kultūra yra visas tarpininkauti padedančių mechanizmų kompleksas: įrankiai ir kiti materialūs produktai, kalbos, mitologija, moralè, normos, teisè (Назаретян, 2001). Kaip rodo visuomenès vystymosi analizé, dèl vis sudètingesnio žmonių ir aplinkos susiejimo gamta bei žmogus vis labiau susvetimejja. Kurdamas gamtinę realybę, žmogus pamažu praranda natūralias savo gyvensenos šaknis, natūralią gamtinę savo egzistencijos determinaciją. Kartu gamta yra instinktyvi žmogaus buveinè, be jos jis nesugeba egzistuoti kaip biologinè rūšis. Tačiau ne mažiau svarbi ir reali žmogaus aplinka yra kultūra, kurianti instinktyvią elgesio - sąmoningo elgesio - sistemą (Бахарев, 1999). Ekologine sąmone pasi- 
žymintis žmogus niekad nepažeis aplinką saugančių įstatymų ir savo profesinėje veikloje nenaudos technologijų, kurios gali pažeisti trapią pusiausvyrą tarp dirbtinès ir natūralios aplinkos, todèl ekologinę sąmonę skirtingose gyventojų grupėse reikia formuoti kryptingomis švietimo ir kitų visuomeninių struktūrų pastangomis.

Tad pamąstykime apie savo kilnujj pašaukimą pasaulyje, pažadinkime savyje neegoistinę sąmonę ir po didelių mokslo atradimų revoliucijų atraskime save savyje, savo tikraji kilnumą ir savo žmogiško orumo vertę. Šios globalios dvasinès ir ekologinès krizès situacijoje žmonija gali ir privalo siekti vienybès su ją supančia gamta ir jai padarytomis neigiamomis pasekmėmis, kurių daugiau neturètų kartoti, jaučiant atsakomybę dèl ateities kartų, jų gyvenimo kokybès.

\section{Išvados}

1. Darnumas yra normatyvinis etinis principas, taikomas tolesnei visuomenès plètrai, bylojantis ne tai, kaip yra, bet tai, kaip turètų būti.

2. Meilè, pagarba ir moralinis imperatyvas natūraliam žemès grožiui, būtinybe išsaugoti gamtos ịvairovę leidžia apibūdinti darnų vystymąsi kaip etinị idealą.

3. Vienintelè reali išeitis iš scientistinès aklavietès - tolesnè darnumo etikos plètra, atkuriant vientisą pasaulio vaizdą ir žmogaus ryšş su gamta.

4. Reikia ieškoti alternatyvių žmonių elgesị nusakančių koncepcijų, kai lemiamu žmonių visuomenès veiksniu tampa moralumas, suvokiant savo atsakomybę aplinkiniams ir visuotinę grèsmę aplinkos ateičiai.

5. Sinerginis antropocentrizmas - tai ne grị̌imas ị praeitị, o greičiau spiralinis progresas, grąžinantis ị tą pačią vietą, tik jau kitoje, aukštesnèje, spiralès vijoje. Šiuolaikinè realybė tokia, kad būtent žmogus sugeba užtikrinti ne tik civilizacijos, bet ir visos Žemès planetos tolesnį vystymąsi arba žūtį.

6. Darnaus vystymosi filosofijos sampratą apima ir ekologinis vientisumas, ekologinè kultūra, ekologinis sąmoningumas, socialinis ir ekonominis teisingumas, nesmurtiniai veiksmai, demokratija ir taika.

7. Ekologiniu sąmoningumu pasižymintis žmogus niekad nepažeis aplinką saugančių ịstatymų ir savo profesinejje veikloje nenaudos technologijų, kurios gali pažeisti trapią dirbtinès ir natūralios aplinkos pusiausvyrą.

8. Dèl sparčios mokslinès technologinès plètros kyla išnaudojimo ir sunaikinimo problema, kurią išspręsti gali žmogaus „ekologinis atsivertimas“.

9. Žmogus privalo mažinti savanaudišką vartotojiškumą, būtų geriau, kad vietoj savanaudiško vartojimo jis siektų büti ir tobulèti, o ne turèti ir mégautis. 
Remigijus Čiegis, Algirdas Gavenauskas, Anželika Dautartė, Juozas Pekarskas, Rūtenis Jančius

10. Ekonominiam vystymuisi svarbios sukurtos gėrybės, kurios skatina mokslinę ir technologinę pažangą. Sukurtos gėrybès, jų valdymas žmoniją turètų labiau skatinti įprasminti savo žmogiškaji pašaukimą pasaulyje.

11. Žmonija, prièmusi darnaus vystymosi žinias kaip tiesą, formuosis naują požiūrị ì pasaulị, ugdysis ịūdžius priimti matomą pasaulị kaip dovaną, tai turètų tapti įpročiu tarnauti kitiems ir pasauliui, siekiant darnumo.

Gauta 20170401

Pasirašyta spaudai 20170522

\section{Literatūra}

Baranova, J. (2002). Etika: filosofija kaip praktika. Vilnius.

Barbour, I. (2000). When science meets religion. New York.

Brown, D. A. (1994). The ethical dimensions of the United Nations program on environment and development. Earth Ethics Research Group.

Covey, S. R. (2007). 8-asis iprotis. Vilnius: Alma littera.

Čiegis, R. (1997). Tolydi ekonomikos plètra. Kaunas.

Čiegis, R. (2002). Tolydi plètra ir aplinka: ekonominis požiūris. Vilnius.

Čiegis, R. (2004). Ekonomika ir aplink: subalansuotos pletros valdymas. Kaunas.

Daly, H. E., Cobb, J. B. (1989). For the Common Good: Redirecting the Economy Toward Community, the Environment and Sustainable Future. Boston.

Ekologija teologijos požiūriu. Prieiga internete: //http://www.baznycioszinios.lt/old/bz9710/710str2.html [žiūrèta 2017-04-15].

Engel, J. R., Denny-Hughes, J. (1994). Advancing ethics for living sustainably. Report of the IUCN ethics workshop, April 1993, Indiana National Lakeshore, USA, Sacramento.

Engel, J. R., Engel, J. G. (1990). Ethics of environment and development: Global challenge, international response. London.

Griffin, D. R. (1999). Religion and scientific naturalism: overcoming the conflicts. New York.

Gustainis, E., Jankauskienè, L., Pakalnis, R., Taločkaitè, E., Vèbra, E. (2002). Subalansuotosios plètros igyvendinimo nacionaline ataskaita. Vilnius.

Hubbert, M. K. (1992 [1976]). Exponential Growth as a Transient Phenomenon in Human History [1976]. In: H. Daly, K. Townsend (eds.). Valuing the Earth: Economics, Ecology, Ethics [1992]. Cambridge.

Jonas Paulius II. (1979). Apaštalinis laiškas „Inter sanctos “. Prieiga internete: http://w2.vatican.va/content/johnpaul-ii/la/apost_letters/1979/documents/hf_jp-ii_apl_19791129_inter-sanctos.html [žiūrèta 2017-04-22].

Jonas Paulius II. (1979). Enciklika „Redemptor hominis“. Prieiga internete: http://www.lcn.lt/b_dokumentai/ enciklikos/redemptor-hominis.html [žiūrèta 201704 22].

Jonas Paulius II. (1981). Enciklika „Laborem exercens“. Prieiga internete: http://www.lcn.lt/b_dokumentai/ enciklikos/laborem-exercens.html [žiūrèta 201704 25].

Jonas Paulius II. (1987). Enciklika ,,Sollicitudo rei socialis“. Prieiga internete: http://www.lcn.lt/b_dokumentai/ enciklikos/sollicitudo-rei-socialis.html [žiūrèta 201704 25].

Jonas Paulius II. (1991). Enciklika „Centesimus annus“. Prieiga internete: http://www.lcn.lt/b_dokumentai/ enciklikos/centesimus-annus.html [Žiūrèta 201704 25].

Jonas Paulius II. (1995). Enciklika „Evangelium vitae“. Vilnius: Aidai.

Kalenda, Č. (1996). Ekologinis-dorovinis imperatyvas: ištakos ir turinys. Problemos, Nr. 49, p. 61-68.

Kalenda, Č. (1998). Gamta, žmogaus veikla ir dorovè. Humanistica, Nr. 1, p. 35-37.

Kalenda, Č. (2002). Ekologinè etika: ištakos ir dabartis. Vilnius.

Kothari, R. (1994). Environment, technology and ethics. In: L. Gruen, D. Jamieson (eds.). Reflecting on Nature: Readings in Environmental Philosophy. New York, p. 228-230.

Maceina, A. (1992). Raštai, T. 2: Socialiné filosofija. Vilnius: Mintis.

McDaniel, J. (1995). With roots and wings: Christianity in an age of ecology and dialogue. New York. 
Orr, D. (2002). Four challenges of sustainability. Conservation Biology, Vol. 16, p. 1457-1460.

Our Common Future. (1987). World Commision on Environment and Development.

Parker, K. (1993). Economics, sustainable growth, and community. Environmental, Vol. 2, p. $233-245$.

Paulius VI. (1967). Enciklika „Populorum progressio“.

Pivrikas, V. (2008). Ekologija. Žmogus. Sveikata. Klaipėda.

Pranciškus. (2015). Enciklika „Laudato si“. Kaunas: Katalikų interneto tarnyba.

Rockefeller, S. C., Elder, J. C. (1992). Spirit and nature: Why the environment is a religious issue. Boston.

Skolimowski, H. (1990). Reverence for life. In: J. R. Engel, J. G. Engel (eds.). Ethics of environment and development: Global challenge, international response. London, p. 97-103.

Šventasis Raštas. (1998). Vilnius: Lietuvos katalikų Vyskupų Konferencija, Katalikų pasaulis.

Tarptautinè teologijos komisija. Bendrystė ir tarnystè. Prieiga internete: http://www.vatican.va/roman_curia/ congregations/cfaith/cti_documents/rc_con_cfaith_doc_20040723_communion-stewardship_lit.html [Žiūrèta 201704 22].

Turner, R. K. (1988). Wetland conservation: economics and ethics. In D. Collard, D. W. Pearce, D. Ulph (eds.). Economics, Growth and Sustainable Environment. London.

Vatikano II Susirinkimo nutarimai. Gaudium et spes. (2001). Lietuvos Vyskupų Konferencija. Vilnius: Aidai.

Бахарев, В. В. (1999). Экологическая культура как фактор устойчивого развития социума. Ульяновск.

Брудный, А. А. (1998). Психологическая герменевтика. Москва.

Данилов, В. В., Данильян, М. Ч., Залиханов, К. С. Лосев, К. С. (2007). Экологическая безопасность. Общие принцииы и российский аспект. Москва: Бимпа.

Кошелева, В. (1993). Экология и нравственность. Общественные науки и современность, № 1, с. 153-162. Кужанова, Н. И. (2005). Экологическое сознание в статегии устойчивого развития. Санкт-Петербург.

Назареян, А. П. (2001). Цивилизационньле кризисы в контексте универсальной истории. Москва: Пер. СЭ. Петрова, Г. Д. (2005). Экологический потенциял сознания и устойчивое развитие. Санкт-Петербург.

Шмелева, И. А. (2005). Ценности и профессиональная мотиваџия как одна из проблем психологического обеспечения образования для устойчивого развития. Санкт-Петербург.

\title{
SUSTAINABLE ECONOMIC DEVELOPMENT: ETHICAL AND SPIRITUAL FUNDAMENTALS
}

\author{
Remigijus Čiegis, Algirdas Gavenauskas, Anželika Dautartė, \\ Juozas Pekarskas, Rūtenis Jančius
}

Summary

Humanity is experiencing an ecological crisis, which occurs as uncontrolled human activity. Ecological crisis encourages humanity to choose the way forward, which is to not deny the advances and the progress of science, but is the fruit of creativity and the mission given to man. Ecological crisis requires a person's inner conversion - ecological conversion, because this crisis affects the relationship between man and the surrounding world. World gifted to man with all its treasures - goodness, according to the need should reach all people. Humanity consumerism is gone beyond the limits of justice, because this wealth is used by distorting the quality of life and justice. In this context it should be a concern of environ- 
mentally friendly idea of sustainable development that would allow humanity to use the high standard of living without destroying the natural and biological foundations. There is a need for a change determining harmonious relationship between man and nature, the development of which requires the transformation of the inner person associated with human culture, values, lifestyle and worldview change.

This article aims to distinguish the fundamental human and natural relations manifestations, to provide ideological connection of ecological ethics and application possibilities raising a harmonious, responsible human relationship with nature, in order to maintain a healthier, less anthropogenic activities affected environment for future generations, to highlight certain ethical provisions providing moral entities optimistic hope align civilization achievements with eternal humanistic values. Subject of the article - a sustainable development in Christian teaching.

The seventh decade of the XX environmental pollution has reached massive proportions; one of the reasons was the world's demographic explosion. Lack of spiritual awareness began to pose a risk not only to nature but also the man himself. Man has forgotten love of nature, its treasures he began to use for self-centered reasons, and therefore uncontrolled. The words to manage the land, which was to disguise satisfy their selfish goals, was re-adjusted reminding the human responsibility to the world. Distortion of words was decisive destruction of sustainable development to justify their actions. This has become a cause of new sustainable development education seeking for changes in people's minds and actions. These reasons show that the basis of the ecological crisis is not in technological progress, but this is the cultural, religious, psychological and ethical problem. The decision to get out of the ecological crisis is continuity in the development of ethics in order to restore picture of the world and the human relationship with nature. The aim of the new way of life and new way of consumption should be based on a new attitude towards man and the environment.

The ecological and moral criteria are becoming increasingly influencing global change, the health and survival of mankind, but also these criteria is the limit that must not be surpassed humanity. Sustainable development is seen primarily human; as a whole and the inner spiritual world calling parameters. Agriculture and food products, which occur in terms of advances is not denied in the context of sustainable development but humanity is at risk of sinking in the goods consumption. Today newly must berealized that the earth is a gift to mankind, and man is called to participate in sustainable development using those received goods. Through a vocation person must be able to make sense of possession, management and use. Along today's humanity must overcome internal chaos in managing the inner life. Humanity cannot forget its main task - to stop exploiting nature, to start to cooperate with the surrounding beauty and goodness, in particular that each person has inside. 
Environmental consciousness is directed at individual and societal risks liquidation, at the same time focused on ensuring the awareness of nature and the subject steady state. Sustainable development is perceived primarily as a consumption reduction, reduction of population growth, but it is not responsible for the development, as a growing process. Ecological man must be oriented to the coherence, harmony, harmony with nature, but not to fight with nature. Ecological consciousness - a tool to defend against the lurking dangers, threats, claims, and therefore it is resolving psychological problems. The inability to deal with own psychological problems has become a consequence of which is the realization of the problems in relation to nature.

Human inner transformation may be way out in reducing the spiritual moral and social crisis of human identity, the identity of the inner depletion increasing the area of mental self-awareness, without creating safety, the "alleged" order of the spirit numbness, heart counteraction, the price of internal living life emptying; taking care of not only own, but the other person's presence alongside, creating and sustaining cultural climate, which are essential for the other, more significant steps in strengthening human dignity and sustainable development conception. Sustainable economic solutions will become environmentally friendly when with change of people's fundamental values and the emergence of new ethics, will arise a new approach to nature and the responsibility of all mankind maintaining a healthy relationship with nature. Ecological ethics is a new branch of science seeking to harmonize the use of the environment, also to put on the line global moral principles, protect the right of existence to the being, respect for life and the harmonious development of society and nature. The moral content, moral progress speed, by supplementing it with new principles and maxims that promote nurturing nature, is an important for environmental ethics. Ecological ethics seek a fair, healthy and meaningful human life on earth, fostering life.

Mankind required morally sustainable development, which will help successfully address the environmental issues. Sustainable economy could become a sustainable development objective, but for must be ensured the vital basic needs of the people currently living on earth; and with a priority for future generations. Ecological consciousness can ever be the basis for storing intact environment laws and in professional life - not to use technologies that infringe equilibrium between the artificial and the natural environment. Education and other public bodies can become an instrument of ecological consciousness formations at different population groups. Finally, if humanity will take sustainable development knowledge as truth; then will be able to shape a new approach to the world in themselves, will acquire the skills to take the visible world as a gift, and it should become a habit to serve others and to the world, to ensure coherence. 
